\title{
The First Record of Aceria sacchari Wangon, an Eriophyoid Mite, in Sugarcane Plantations in Sri Lanka
}

\author{
V.K.A.S.M. Wanasinghe* ${ }^{1}$, K.M.G. Chanchala ${ }^{1}$, D.Navia ${ }^{2}$, L. Nugaliyadde $^{3}$ and N.S.Aratchige ${ }^{4}$ \\ ${ }^{1}$ Sugarcane Research Institute, Uda Walawe, Sri Lanka \\ ${ }^{2}$ Embrapa Recursos Geneticos e Biotenologia, Brazil \\ ${ }^{3}$ Sri Lanka Organization of Agriculture Professionals, Department of Agriculture, Peradeniya \\ ${ }^{4}$ Coconut Research Institute, Bandirippuwa Estate, Lunuwila, Sri Lanka \\ DOI: 10.29322/IJSRP.8.9.2018.p8137 \\ http://dx.doi.org/10.29322/IJSRP.8.9.2018.p8137
}

\begin{abstract}
Some warty patches slightly raised from the surface of the leaf sheath of some sugarcane plants in a sugarcane field at Sevanagala $\left(6^{0} 36^{\prime} \mathrm{N}, 80^{\circ} 87^{\prime} \mathrm{E}\right)$, Sri Lanka, were observed during a field inspection in July 2016. These patches were irregular in shape and watery in appearance initially. Later, they become dry and reddish to dark red in colour. Microscopic examination on the damaged leaf sheaths showed large a population of minute mite. This study was conducted from July to September 2016 to identify this mite species and to investigate its damage symptoms and the occurrence in all sugarcanegrowing areas in Sri Lanka. Two hundred specimens of the mite were sent to Embrapa Recursos Geneticos e Biotenologia, Brazil, for identification. Fifty mite-infested plants from each age category, $<5$ months and $>5$ months, were inspected to study the damage symptoms and fifty randomly selected plants from each age group were inspected to record the damage incidence in the plantations in each sugarcane-growing site; Uda Walawe, Sevanagala, Pelwatte, Hingurana, Ethimale and Kantale. The specimens were identified as Sugarcane Blister Mite, Aceria sacchari Wang, 1964 (Acari: Trombidiformes: Eriophyidae). This is the first record of this mite on sugarcane in Sri Lanka. This mite has distributed in all sugarcane-growing areas in the country with different infestation levels. During the study period, the highest damage incidence on both age groups was recorded at Pelwatte while the lowest was at Hingurana.
\end{abstract}

Index Terms- Aceria sacchari, Eriophyoid Mite, Sugarcane Blister Mite, Sri Lanka

\section{INTRODUCTION}

Qugarcane is attacked by a variety of mites belonged to the $\checkmark$ Tetranychidae, Tarsonemidae and Eriophyoidea families. Most of these mites are considered as minor pests (OzmanSullivan et al., 2006). Among them, researchers have given high priority to the family Eriophyoidea, a superfamily of herbivorous mites, because it includes the smallest known species of mites and their damage is often attributed to other problems such as disease or malnutrition. The Eriophyoids are among the most diverse and economically important group of phytophagous mites. They are the highly-adapted plant-feeding mites living extremely intimate association with their host plants (Petanovic and Vidovic, 2009). They are among the smallest arthropods in the world, and this is the key to their ecological success (Sabelis and Bruin, 1996).

So far, nine species of Eriophyoidea mites have been reported on sugarcane, namely Abacarus delhiensis, Abacarus queenslandiensis, Abacarus doctus, Abacarus sacchari, Aceria sacchari, Aceria merwei, Cathetacarus spontaneae, Catarhinus sacchari and Diptacus sacchari (Ozman-Sullivan et al., 2006; Navia et al., 2011). Abacarus doctus is the only sugarcaneassociated eriophyoid mite in Costa Rica (Navia et al., 2011) and El Salvador (Guzzo et al.,2014), causing clear symptoms of reddish or bronzed spots on the inner leaf surface, which is similar to those caused by rust fungi. Among them, the leaf vagrant, Aceria sacchari causes occasional chlorotic blotches on the leaves, which is symptomatically similar to the damage caused by thrips or some fungi. It is a potential vector of plant viruses, but the transmission mechanism has not been proven (Ozman-Sullivan et al., 2006). It has been assumed as a possible vector of sugarcane streak virus (ChannaBasavanna, 1996).

After establishment of the commercial sugarcane cultivations in Sri Lanka in the early 1960s, only one species of sugarcane leaf mite of the family Tetranychidae (sugarcane yellow mite; Oligonychus sacchari) has been reported. They live and feed on the underside of leaves forming fine webs, in which eggs are laid and young nymphs develop. The affected leaves become discoloured and severe damage can result in dying leaves. A severe infestation of a mite species was observed on the variety SL 96128 in 2012 and 2013 in the seedcane nurseries of the Lanka Sugar Company (Pvt) Ltd. Pelwatte, Sri Lanka. It was successfully controlled by the dominant biological control agent; Stethorus sp. (Coleoptera: Coccinellidae).

A hitherto unknown mite species living in distinct colonies on the inner surface of leaf sheaths of sugarcane was observed in July 2016 in sugarcane cultivations at Sevanagala $\left(6^{0} 36^{\prime} \mathrm{N}, 80^{\circ}\right.$ $87^{\prime} \mathrm{E}$ ) in the dry zone, during a pest survey conducted by the Sugarcane Research Institute (SRI), Sri Lanka. Studies were conducted to identify this mite species and to investigate its damage symptoms and the occurrence in all sugarcane-growing areas in Sri Lanka from July to September 2016.

\section{MATERIALS AND METHODS}

\section{Identification of the Mite Species}


Two hundred specimens of the mite species were collected from infested leaf sheaths of sugarcane in the Research Farm of the Sugarcane Research Institute at Uda Walawe $\left(6^{0} 27^{\prime} \mathrm{N}, 80^{\circ}\right.$ 52'E), Sri Lanka. The alcohol preserved specimens were dispatched to Dr. Denise Navia, Embrapa Recursos Geneticos e Biotenologia, Brazil, for identification. The specimens were then slide-mounted in modified Berlese medium using a dissecting stereomicroscope and identified using a combined phase-contrast and differential interference contrast microscope (NikonEclipse 80i, Nikon, Tokyo, Japan).

\section{Study on Damage Symptoms}

Fifty mite-infested sugarcane plants from each age category, $<5$ months and $>5$ months, in the Research Farm at Uda Walawe, commercial sugarcane plantations at Sevanagala $\left(6^{0} 36^{\prime} \mathrm{N}, 80^{\circ} 87^{\prime} \mathrm{E}\right)$, Pelwatte $\left(6^{\circ} 45^{\prime} \mathrm{N}, 81^{0} 14^{\prime} \mathrm{E}\right)$ and Hingurana $\left(7^{0} 13^{\prime} \mathrm{N}, 81^{\circ} 39^{\prime} \mathrm{E}\right)$ and seed cane nurseries at Ethimale $\left(6^{\circ} 77^{\prime} \mathrm{N}\right.$, $\left.81^{0} 49^{\prime} \mathrm{E}\right)$ and Kantale $\left(8^{0} 22^{\prime} \mathrm{N}, 81^{\circ} 1^{\prime} \mathrm{E}\right)$ were inspected and the damage symptoms were observed. Also digital photographs were taken and sent to Embrapa Recursos Geneticos e Biotenologia, Brazil, for identification.

\section{Incidence of the Mite Species in Sri Lankan Sugarcane- growing Areas}

Field surveys were conducted in the research farm at Uda Walawe, commercial sugarcane plantations at Sevanagala, Pelwatte and Hingurana and seed cane nurseries at Ethimale and Kantale to study the damage incidence of the pest. From each location, 50 plants from the each age category ( $<5$ months and $>$ 5 months) were randomly selected to record the damage incidence of the mite species by inspecting all the leaf sheaths. The percentage damage incidences in all the locations were estimated.

\section{RESULTS AND DISCUSSION}

\section{Identification of the Mite Species}

The mite species was identified as Aceria sacchari Wang, 1964 (Acari: Eriophyidae). This is the first report of A. sacchari from sugarcane in Sri Lanka. This species is commonly known as sugarcane blister mite, and it has been reported from India (Muthukrishnan, 1956), Indonesia, Java (Van Hall, 1923), Taiwan (Wang, 1964) and Queensland, Australia (Box, 1953).It is an interesting species having two female forms, one with slender body and 6-rayed feather claws and the other with thicker body and 7-rayed feather claws. The two forms are identical in all other features, such as shield design and setal pattern (Channa Basavanna, 1996). Also it has prodorsal shield with nearly complete median, admedian and submedian lines, lateral shield with granules, opisthosomal seta $e$ (second ventral seta) much longer than seta $f$ (third ventral seta) and empodium 6-7 rayed feather claws (Ozman-Sullivan et al; 2006).

\section{Study on Damage Symptoms}

The mite A. sacchari lives in distinct colonies on the inner surface of leaf sheaths. The infested areas can be seen as warty patches slightly raised from the surface (Blister) of the leaves. These patches are irregular in shape and watery in appearance initially. Later, they turn into reddish to dark red in colour and become dry (Figure 1, A and B). The feeding of A. sacchari causes large spots with 1-2 cm diameter on both sides of sheaths. Hypertrophied spherical leaf blisters contain mite populations (Wang, 1964; ChannaBasavanna, 1966; Jepson et al., 1975).
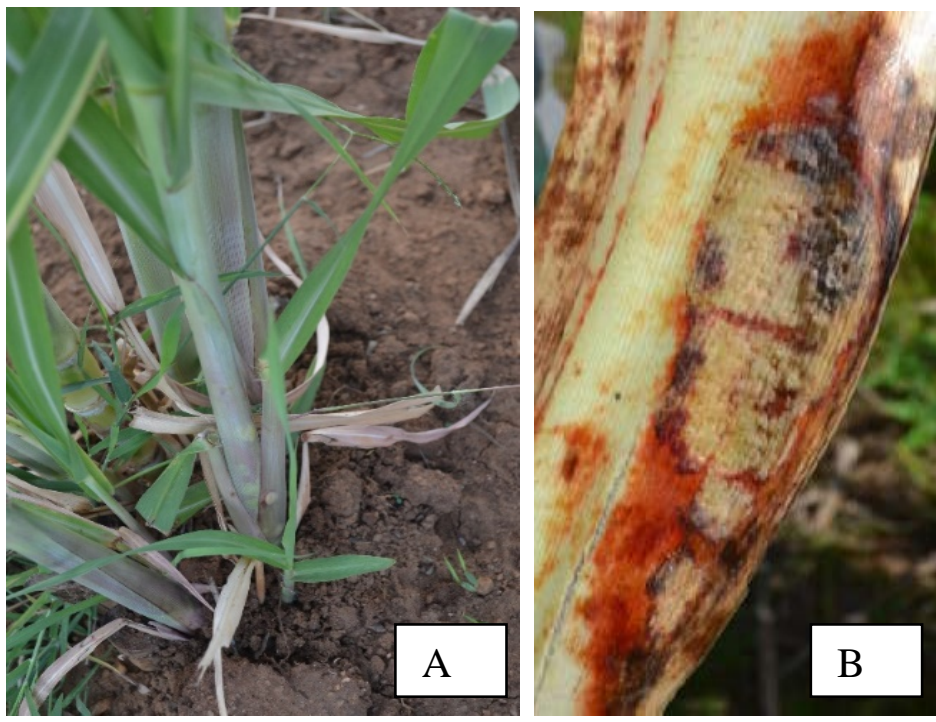

Figure 1: A-External appearance (warty patches) on sugarcane leaf sheathes infested by A. sacchari; B-Internal appearance of an infested leaf sheath

Most of the young (1-3 months old) sugarcane plants having "Dead Heart" symptom without the damages of sugarcane shoot borers; Sesamia inferans (Lepidoptera: Noctuidae) and Chilo sacchariphagus (Lepidoptera: Crambidae) were found to be infested with A. sacchari. It may be due to the infestation of the $A$. sacchari because the damage on the leaf sheath due to sugarcane blister mite can predispose to the infection of the damage site by saprophytic fungi such as Gleosporium sp., Fusarium sp. and Alternaria sp. (Muthukrishnan, 1956).

\section{Incidence of the Mite Species in Sugarcane-growing Areas}

Infestations of $A$. sacchari were observed in all the inspected sugarcane fields at Uda Walawe, Sevanagala, Pelwatte, Hingurana, Ethimale and Kantale. The highest percentage damage incidences for each age category were recorded at Pelwatte (99\% at $<5$ months age and $98 \%$ at $>5$ months age) the lowest was at Hingurana $(79 \%$ at $<5$ months and $81 \%$ at $>5$ months old crop). It indicated that $A$. sacchari has spread into almost all sugarcane-growing areas in the country with different infestation levels.

\section{FUTURE PROSPECTIVES}

Identification of the morphological, biochemical and physiological characters of susceptible and tolerant/resistant varieties are important for developing tolerant/resistant varieties. It is also necessary to identify potential biological control agents against $A$. sacchari and to study their bio-ecology to establish a successful biological control programme. Predatory mites with flat idiosoma such as Neoseiulus paspalivorus which have been reported to be associated with plants in the Graminae family 
would hold some promise. Eriophyoid mites are easily overlooked and can be disseminated through propagation material (Navia et al, 2011). Therefore, it is very important that the sugarcane germplasm exchanged in the form of stalk pieces among the countries should be free of eriophyoid mites to avoid the dissemination of $A$. sacchari to other countries

\section{ACKNOWLEDGMENT}

The authors acknowledge the assistance of Ms. H. B. M. Hatharasinghe, training student from the National Apprentice and Industrial Training Authority (NAITA), Sri Lanka during the field activities at Uda Walawe. Dr. A.P. Keerthipala, Director/ CEO, SRI for their valuable comments to improve an earlier version of this article.

\section{REFERENCES}

[1] Box, H.E. (1953). List of Sugarcane Insects. Commonwealth Inst Entomology, London, UK. 102 pp.

[2] Channa Basavanna, G.P. (1996). Sugarcane, coffee and tea. In: Lindquist, E.E., Sabelis M.W. and Brun J. (Eds). Eriophyoid Mites- Their Biology, Natural enemies and Control. Elsevier Science Publi., Amsterdam, The Netherlands. Pp 631-640.

[3] Guzzo E.C., Negrisoli Jr. A.S., Cerón-Marti F.A., Lemus, M.A., Benítez D., Navia D. (2014) First report of the eriophyoid mite Abacarus doctus (Prostigmata: Eriophyidae) infesting sugarcane in El Salvador. Florida Entomologist 97: 1835-1836.

[4] Jepson, L. R., Keifer H.H. and Baker E. W. (1975). Mites Injurious to Economic Plants. University of California Press, Berkeley, California, USA, $614 \mathrm{pp}$.

[5] Muthukrishnan, T. S. (1956). An Eriophyoid mite on sugarcane in South India. Curr. Science. 25: 234-235.
[6] Navia D, Flechtmann C.H.W, Lindquist E.E and Aguilar H. (2011). A new species of Abacarus (Acari: Prostigmata: Eriophyidae) damaging sugarcane, Saccharum officinarum L., from Costa Rica- the first Eriophyoid mite described with a tibial seta on leg II. Zootaxa 3025: 51-58.

[7] Ozman-Sullivan S. K, Amrine J.W., Jr and Walter D. E. (2006). A new species of Eriophyoid mite (Acari: Eriophyidae) on sugarcane in Australia. Int.J.ofAcarol. 32(4). pp 387-395.

[8] Pentanovic, R. and Vidovic, B. (2009). New Acaricalus species (Acari: Eriophyoidea) from Turkey Oak, QuercusCerris L. (Fagaceae) and the new records for the fauna of Serbia. Acta entomologica serbica, 14 (1): 109-120.

[9] Sabelis M.W and Bruin J. (1996). Evolutionary Ecology: Life history patterns, food plant choice and dispersal In: Lindquist E.E., Sabelis M.W. and Bruin J. (eds.) Eriophyoid Mites - Their Biology, Natural Enemies and Control. World Crop Pest Series Vol. 6. Elsevier Science Publishers, Amsterdam, The Netherlands, pp. 329-366.

[10] Van Hall C.J.J. (1923). Diseases and pests of cultivated plants in the Dutch East Indies in 1922, Meded. Inst. Plantenziekten, 58, 42 pp., (Abstract in Review Applied Ent.12: 572).

[11] Wang C. (1964). A new blister mite on sugarcane in Taiwan, Aceria sacchari n.sp. Rep. Taiwan Sugar Experiment Station.33: 83-94.

\section{AUTHORS}

First Author - V.K.A.S.M. Wanasinghe, Sugarcane Research Institute, Uda Walawe, Sri Lanka

Second Author - K.M.G. Chanchala, Sugarcane Research Institute, Uda Walawe, Sri Lanka

Third Author - D.Navia, Embrapa Recursos Geneticos e Biotenologia, Brazil

Fourth Author - L. Nugaliyadde, Sri Lanka Organization of Agriculture Professionals, Department of Agriculture, Peradeniya

Fifth Author - N.S.Aratchige, Coconut Research Institute, Bandirippuwa Estate, Lunuwila, Sri Lanka 